\title{
An Analysis of the critical strategic dimensions for internalization of Brazilian firms in global base-of-pyramid (BOP) markets
}

\author{
Renata Giovinazzo Spers ${ }^{\dagger}$ \\ University of São Paulo \\ James Terence Coulter Wright ${ }^{\Omega}$ \\ University of São Paulo
}

\begin{abstract}
This paper presents the critical strategic dimensions to operate in international Base-ofPyramid (BOP) markets. The variables studied are reasons for internationalizing: prices, promotion, distribution, products, innovation, entrance into markets and processes. A descriptive, exploratory, multiple-case research was developed with the Brazilian firms Natura, O Boticário, AmBev, Embraco, Perdigão and Havaianas. Longitudinal and comparative analyses led to the conclusion that the main reason for entrance in international BOP markets is increased long-term sales and earnings. Critical strategic dimensions are brand management, adequate product mix, process innovation, relationships with stakeholders and corporation culture strengthening.
\end{abstract}

Keywords: International strategies; base-of-pyramid (BOP) markets; Brazilian multinational companies.

*Corresponding Authors:

${ }^{\dagger}$.Doctor at University of São Paulo

Affiliation: Professor at University of São Paulo. Address: Av. Prof. Luciano Gualberto, 908-Sala G163-São Paulo - SP - Brazil

E-mail: renatag@usp.br

Telephone: (11)3091-5848
${ }^{\Omega}$ Doctor at University of São Paulo.

Affiliation: Professor at University of São Paulo.

Address: Av. Prof. Luciano Gualberto, 908-Sala G163-São Paulo - SP - Brazil

E-mail: jtwrigt@usp.br

Telephone: (11)3091-5848 


\section{INTRODUCTION}

his study combines two elements that are both current and relevant. One is the existence of firms which focused on the low-income market in Brazil - which itself has had an excellent performance in the last years - and that have a consistent and well-defined strategic profile, according to a survey done by Giovinazzo (2003). The other is the huge international Base-of-Pyramid (B.O.P.) market, made up of low-income population, as described by Prahalad (2005) and Cardoso (2005), which has excellent performance potential for Brazilian firms which already have the experience, scale and strategies to serve a low-income public.

According to Giovinazzo (2003), there are firms successfully operating in the popular goods market in Brazil, developing and maturing adequate strategies to supply a low-income population with standard, simple, low-cost products, but with good quality and accessible prices. A series of possibilities now present themselves for these firms to continue their growth, but one in particular seems very opportune: the possibility of exploring other lowincome markets for popular goods around the world. This may be a once-in-a-lifetime opportunity, because there are huge markets not fully supplied by local or traditional US, European and Japanese firms, which themselves have concentrated on more expensive and sophisticated products and only recently begun to supply the low-income, popular goods markets. In this undertaking, according to studies by Hart and Milstein (1999), London and Hart (2004) and Prahalad (2005), they have encountered difficulties.

Within this scope the main aim of this study is to answer the question, "What are the critical strategic dimensions for Brazilian companies' performance in international B.O.P. markets?"

The strategic dimensions subjected to analysis in this study were based on the theoretical framework and are as follows. In relation to international performance, Brazilian firms in the advanced stages of internationalization are considered, using the definitions supplied by Johanson and Vahlne (1977). Consequently, the firms analyzed in this study are those with commercial or production branches in other countries.

We considered as international low-income markets all of the markets outside Brazil whose yearly per capita income is below US\$9,385 and where more than one million inhabitants have an annual income between US\$765 and US\$9,385. This definition was proposed by Cardoso (2005) and is in alignment with the definitions in the World Bank's 
annual World Development Report. Based on this definition, Cardoso (2005) analyzed international low-income markets with the highest potential for Brazilian firms using an adapted gravitational model, which considered cultural, political, administrative, geographic and economic aspects, and identified the twenty most attractive international low-income markets with the highest potential for Brazilian firms: Argentina, China, Colombia, Mexico, India, Chile, Russia, Peru, Paraguay, Venezuela, Uruguay, South Africa, Turkey, Iran, Poland, Algeria, Saudi Arabia, Indonesia, Thailand and Bolivia. These are the international low-income markets considered in this work.

Given this context and the definitions presented, this work aims at presenting critical strategic dimensions for Brazilian firms to successfully compete in international low-income markets, based on the analysis of cases of Brazilian firms in the light of the theoretical framework and following a research protocol for theory elaboration.

\section{INTERNATIONALIZATION STRATEGIES: CONCEPTS AND STRATEGIES FOR LOW-INCOME MARKETS}

\subsection{Reasons for internationalizing}

According to Valdés (2003), internationalization is seen as a possible growth strategy for organizations. Different authors discuss additional reasons for the international operation of firms. Whitley (2001) emphasizes that the growth of foreign direct investments and organizational coordination of economic activities across national borders have been seen as key features in the increase in globalization. Adding to this view, and in the light of global trends, Daniels \& Daniels (1996) emphasize the importance of a global performance for firms, not only to increase sales and gain new markets, but also to face competition, stay up to date in relation to new tendencies, and create advantage in the development of new business opportunities.

Mintzberg and Quinn (2001) posit that operating in an international arena presents a host of opportunities for managers, providing access to new markets and specialized resources and also opening new sources of information which can help the development of future products. According to Ansoff (1984), a firm that goes international can be motivated by a number of factors. There are operational needs, such as ensuring the supply and maintenance of capital goods, the supply of raw material, and the availability and use of technology. In addition, there is the need to distribute final production surplus, or strategic needs, such as ensuring the firm's survival in relation to future changes in the environment; ensuring continuing growth by maintaining the historical growth tendency and avoiding slumps caused 
by saturation, and finally, the need to increase the volume of business or increase the growth rate and ensure and increase rentability.

Hamel and Prahalad (1985) defend the advantages of adopting global corporate strategies, arguing that buyers' needs have become more homogeneous, whereas Deresky (2004) outlines competitive strategies such as the establishment of economies of scale, production abroad and international cash flow, all with a global reach.

While considering more specific reasons for the internationalization of Brazilian firms, we identified other motivations for Brazilian firms to establish branches abroad. These include market growth, since firms usually already have a strong participation in the domestic market, consolidation of activities, survival, due to a stagnated domestic market, opportunities for international performance, and finally, firms' strategic decisions. Cyrino \& Barcellos (2006) also address motivations for the internationalization of Brazilian firms, emphasizing growth in the sense of expansion to new markets. They also highlight the diversification of risks. Yet another reason, little discussed, is the acquisition of abilities to operate outside the country of origin. In this case, the subsidiaries or branches start to play a strategic role that goes much beyond implementation of the current business. They serve as antenna in experimental projects and are able to integrate new learning and consolidated experiences, thereby increasing the repertoire of experiences available to the firm which can then be applied in other places, including the country of origin.

Taking into consideration the relatively low cost of Brazilian labor, it is unusual for Brazilian firms to go international in search of cheaper labor, according to Cyrino \& Barcellos (2006).

There are various and diverse reasons for internationalization, depending on the sector's characteristics and the context in which firms operate. In dealing with the reason for internationalization in low-income global markets, we can consider some additional factors, according to studies by Meyer (2004) and Marinov and Marinova (2000), which show that foreign investments in emerging countries are mainly motivated by the opportunity to build a long-term position in the market, as well as gain access to the domestic market and profit from qualified labor existing in the region.

\subsection{Firms' strategy in international low-income markets}

The purpose of this item is to present the main concepts related to the companies' operation in international popular-goods markets, from which it is possible to identify the 
research variables regarding the choice of international business segments and markets, as well as the strategic dimensions for internationalization of the Brazilian companies in BOP markets.

\subsubsection{Geographical scope and segments covered}

With respect to the geographical scope, considering the concepts and studies presented by Khanna, Palepu and Sinha (2005), it is possible to say that the economic variables are fundamental to the choice of markets, especially the GDP, growth rates of income per capita, PPP (Purchasing Power Parity) income and exchange rates. In this respect, the openness of the economy is also relevant, and the greater the openness, the more the multinational companies can benefit from global and local middlemen.

However, these economic conditions are not sufficient for companies to define their geographical scope of operations successfully. In this sense, authors Kuada \& Sorensen (2000), Kirsch, Laird \& Evans (2000) and Kirkbride \& Ward (2001) also highlight the issues that involve the population, politics and governance, to define the geographical scope: population composition and rates of population growth; governance indicators, such as levels of corruption; weight of popular-goods markets in investment funds and forecasts of political transition; relations among ethnic, regional and linguistic groups as well as the power centers in each country (bureaucracy, media, society).

Calori, Atamer and Nunes (2000) supplemented this view on the economy, politics and society by highlighting the importance of analyzing the product market, labor market and capital market, as follows:

- product market, involving the gathering of information about consumers, consumption patterns, market survey and advertising;

- labor market, considering that it is usually necessary to recruit talent for companies, both at higher hierarchical levels and at lower levels, including middle managers, engineers and plant supervisors;

- capital market, considering that it is necessary to have accurate information about the market and companies; it is also necessary to assess the corporate governance, local laws and joint-venture agreements.

Finally, Cardoso (2005) analyzes the importance of the cultural distance between Brazil and the markets where the companies are expected to do business, taking into account the fact 
that the cultural similarities or differences can boost or hinder business in the countries where they intend to operate.

With respect to developing markets, it is worth assessing the segments that make it up, using the classification of Mahajan \& Banga (2006): rich and super rich, middle class, poor and rural people. This classification of segments is fundamental to a better understanding of the operation of Brazilian firms in international popular-goods markets, detailing the focus of their operations and the potential for doing business in low-income segments (which include part of the middle class, the poor and the rural population, as happens in Brazil).

\subsubsection{Strategic dimensions for internationalization}

In this item we analyze the strategic dimensions for the operation abroad: prices, promotion, distribution channels, products and services, innovation and technology, ways to enter the selected markets and, finally, production processes and costs.

With respect to prices, according to Daniels \& Daniels (1996), Yip (1996), Keegan \& Green (1999), the decisions concerning prices that will be adopted in the markets result from integrated actions that involve the countries' offices and the headquarters, but the prices may be independently defined in local BOP markets. The pricing strategy may consider predatory pricing (use of the price variable as a competitive weapon to put weak competitors out of business), multipoint pricing (strategies in a market that have an impact on prices of competitors in another market) and the experience curve. As a complement, Hill (2005) says that companies need to consider the regulations in the countries where they operate, especially anti-dumping policies and policies that promote competitiveness. London \& Hart (2004) and Prahalad (2005) analyze the degree of participation of local partners in the pricing strategy, with the purpose of tailoring such strategy to the specific needs and conditions of the populargoods markets.

With respect to the promotion dimension, particularly the marketing approaches to brands, advertising and ways of reaching customers in local markets, it is possible to standardize the promotion or tailor it to the local market, as analyzed by Keegan (1989), Yip (1996), Kotabe \& Helsen (1999), Keegan \& Green (1999) and Engel \& Blackwell (2000). Authors Giovinazzo (2003), London \& Hart (2004) and Prahalad (2005) stress that it is necessary to educate customers in popular-goods markets, with possible changes in the interface between the product and customers and access to innovative customers that can promote the company's product in the local market. They also analyze the importance of local partnerships to obtain information about customers and to promote the product. 
As for distribution channels, once a company has an entry channel that is suitable for the country where it operates, it must determine how to distribute the product. According to Keegan \& Green (1999) and Hill (2005), it is important to analyze the nature of the products, tastes and buying habits of consumers, market competition and transportation options, as well as the concentration and fragmentation of retail systems. London \& Hart (2004) and Prahalad (2005) emphasize that this is a decision that is extremely relevant to the operation in populargoods markets, given the difficulties of infrastructure that companies may encounter in such markets. Therefore, companies should seek low-cost and effective distribution systems that are suitable for the peculiarities of popular-goods markets. It may be necessary to form partnerships with local distribution channels to face the hardship arising from a precarious structure, and to support these local distribution channels in order to promote the product among consumers of the popular-goods market, replacing or supplementing traditional methods of product promotion.

In general, it is possible to standardize products or services, or to adapt them, so as to satisfy the specific requirements of consumers at the base of the pyramid. According to Giovinazzo (2003), London \& Hart (2004), Ricart et al. (2004) and Prahalad (2005), it may often be necessary to create new solutions in order to serve such markets, through new products or new services that are suitable for the low-income population. The participation of local partners can be relevant to the tailoring of the content or design of new products, making them suitable for popular-goods markets. And it may also be necessary to adapt the degree of added services.

With respect to the development and use of innovation and technology, companies may use technology already disseminated or they may develop technology that is appropriate for the markets where they operate, and the innovations produced may be shared or the technological development may be decentralized, as defined by authors Daniels \& Daniels (1996), Yip (1996) and Castells (1999). With respect to the market at the bottom of the pyramid, Prahalad (2005) advocates the use of hybrid solutions, with the application of advanced technologies, but considering a limited infrastructure. Therefore, standardized interface systems must be suitable for heterogeneous consumers of popular-goods markets. It is also necessary to expand the technological platforms in order to incorporate the specific features of low-income markets.

The choice regarding the entry of the company and its operation in different markets will depend on the nature of the specific advantages that the company has or expects to have 
abroad. And the level and nature of the specific advantages of the investing company determine whether the entry occurs through acquisitions, the establishment of a new business or a variation of these alternatives, according to Cavusgil \& Ghauri (1990), Kuada \& Sorensen (2000), Hitt, Ireland \& Hoskisson (2001). According to Deresky (2004), the possible ways to enter a market include exports, licensing, strategic alliances, mergers and acquisitions, establishment of a subsidiary, franchise, manufacturing contracts, turnkey contracts or management contracts. Authors London \& Hart (2004), Meyer (2004) and Cui \& Lui (2005) point to the peculiarities of popular-goods markets, which involve the understanding of the local social context, collaboration with non-traditional partners that can assist actively in the company's entry and the development of local capacities. Another important decision is about the time to enter the market, as the company can play a pioneering role in the popular-goods markets or it can be a follower, entering the market at a later time.

Finally, with respect to the processes, costs and production structure of the company throughout its value chain, the activities can be concentrated in the country of origin, distributed or duplicated in each country, as discussed by Daniels \& Daniels (1996) and Yip (1996). As a complement, Prahalad (2005) presents analyses that are specific to the populargoods market, such as the gain of economies of scale through the development of solutions that are adaptable to different popular-goods markets; reduction in the number of resources used in production, manufacturing environmentally sustainable products, and serving large popular-goods market without causing the destruction of natural resources.

These conceptual elements were applied to the field research, as described below, with a view to identifying the strategic dimensions that are critical to the operations of Brazilian firms in international popular-goods markets, answering the research question proposed for the study.

\section{METHODOLOGICAL APPROACH}

This study included exploratory and descriptive research, as detailed by Green and Carmone (1988), Gil (1987), Selltiz et al. (1987), Malhorta (1996) and Aaker et al. (2001). A qualitative approach was adopted, which, according to Gonçalves (2004), Yin (1994) and Miles \& Huberman (1994), is useful in in-depth studies to approach indicators or manifested variables for ulterior quantitative studies. Eisenhardt (1989) proposes procedures for building a theory based on the case study which are followed in this research, as detailed below. 


\section{a. Beginning}

In the beginning of the study, the focus and the research question were defined. Definitions were established first in relation to the research problem and in relation to the internationalization theories: strategic dimensions.

\section{b. Selection of cases}

The selection of cases, according to Eisenhardt (1989), helps define the limits of generalization of the theory constructed from the analyses. The criteria used to choose the cases analyzed were:

- Firms whose capital originated in Brazil, supplying at least one international low-income market and at least one traditional market, for comparison purposes, and with commercial and/or industrial operations. The popular-goods markets considered in this study are: Argentina, China, Colombia, Mexico, India, Chile, Russia, Peru, Paraguay, Venezuela, Uruguay, South Africa, Turkey, Iran, Poland, Algeria, Saudi Arabia, Indonesia, Thailand and Bolivia. The traditional markets considered in this study are: United States, Canada, Western Europe countries, Japan and Australia.

- Firms producing consumption goods or delivering services or firms which directly supply consumption goods firms - better suited for the analysis of the market for low-income goods;

- Firms to some extent supplying the low-income goods market in Brazil.

Considering the objective of the study and the above mentioned characteristics, the firms selected are: Natura, O Boticário, AmBev, Embraco, Perdigão and Alpargatas (Havaianas Business Unit).

\section{c. Design of instruments and protocols}

Interviews and document reviews were used in the research, and the definition of the interview protocol was based on the theory.

\section{d. Data collection in the field}

Regarding secondary sources, a documental analysis was conducted of institutional material from the firms, as well as of public information, to prepare a base for the personal 
interviews. A survey was made together with the primary sources to collect the data presented in the analyses. The main instrument for the collection of primary data was in-depth personal interviews with fourteen CEOs and Directors from the selected firms, conducted in Brazil and in China.

\section{e. Data analysis}

After collecting data for each case, a longitudinal analysis was conducted to characterize the variables in each case. As proposed by Eisenhardt (1989), after the longitudinal analysis a crossover analysis was also carried out in a structured and systematic manner, which selected variables based on the theoretical referential to identify subtleties and enable building a theoretical model for the performance of Brazilian firms in low-income international markets.

\section{f. Construction of hypotheses}

The definition of themes, concepts and relationships between the variables starts with longitudinal analyses and cross-sectional analyses of data. The next step was to make a systematic comparison between the information obtained from the cases and the theory previously proposed, in an iterative process. A second step was to check whether the emerging relationships between the constructs suited the evidence of each case.

\section{g. Comparison with the literature}

In this step, the literature was examined by comparing similarities and discrepancies, in the light of the analyses conducted in the cases. This led to greater internal validity and a higher conceptual level of the results.

\section{h. Closing}

In the end, the main conclusions presented in this study were identified. For the closing, Eisenhardt (1989) considers two key points: when to stop adding cases to the research and when to stop comparing theory and the data collected. The author suggests between 4 and 10 is a good number of cases. It is also necessary to consider the saturation of the theory, i.e., when the iterative process generates minimal incremental improvements in the theory generated in the research.

In this research, six cases were analyzed, with as many details as possible in each case, as shown below. 


\section{ANALYSIS OF RESEARCH RESULTS}

The results of the research on six most significant Brazilian firms show that low-income markets do present an opportunity for Brazilian firms to operate, but also involve great challenges. These results are in line with observations by Kirkbride \& Ward (2001) who argue that these markets present a variety of problems for firms, such as legal and political restrictions, difficulty in obtaining market information, high transportation costs due to poor infrastructure, and complicated distribution channels driven by local relationships. According to the authors, a common mistake is the evaluation of the nature and size of these markets, because in practice they are often smaller than initial estimates of the firms and local competitors prove to be more aggressive than expected.

The reasons for going international in the low-income goods market are mainly increases in sales and billing aimed at long-term growth. There is no interest in simply benefiting from short-term opportunities, which may even hurt the brand. Firms seek profitable businesses in the long-term that are sustainable. They also seek economy of scale when considering the capacity of production plants. Not a single firm reported having developed operations in low-income markets in order to build a production platform with lower costs so as to operate in other markets.

No firm reported having developed operations in the international low-income goods market simply due to operational needs, as defined by Ansoff (1984). Cheap labor is not the most sought-after resource for firms, because Brazilian labor and manufacturing costs are relatively cheap and competitive, confirming data presented by Cyrino \& Barcellos (2006), who posit that cases of Brazilian firms going international in order to obtain cheap labor are rare.

On the other hand, the firms are concerned with giving exposure to the brand at the international level, by operating in traditional markets (like O Boticário in the US, Natura in France and Havaianas in Europe, Australia and the US), so that they can compete more successfully in low-income markets. Building brand value through exposition and international validation is often cited as the reason for entering the international marketplace.

Even in low-income markets, brands are important and extremely valuable. This competitive edge can be achieved through investment in brand building, or through the acquisition of local popular brands already known to consumers, as is the case with AmBev. This is a very relevant factor because low-income consumers of popular goods also have brand awareness, according to Prahalad (2005). In analyzing the successes of firms in 
emerging markets, Marinov \& Marinova (2000) identified that part of the competitive advantage arises from the reputation brands enjoy.

Brazilian firms interested in operating in low-income markets must consider the sustainability of overseas markets and whether the firm can operate in them in the long term. If the international operation fails, losses can be more than just financial. Failure can also stain the firm's image both in other international markets and in Brazil.

When asked about low-income markets with the highest potential for their firms, executives from the Brazilian firms analyzed highlighted Russia, India and China. However, with the exception of Embraco and Perdigão, which operate in China and Russia, all the firms reported that operating in these markets presents great challenges. It is worth bearing in mind that both Embraco and Perdigão have not made direct sales to end consumers.

The executives stated that Russia has a high level of corruption, no business transparency and a population with low purchasing power, which makes competition with local products very difficult. It is a market with strong expansion that is still relatively incipient. In China, protectionist market rules hinder the entrance of products, while the supremacy of global brands and the low income available present problems, as does very strong domestic competition that produces very cheap products locally. In India, the culture, consumption habits, and types of products demanded are very different, which hinders the entrance of firms. Low income level and local competition, as well as protectionist laws, make performance in India very difficult for Brazilian firms.

The results of this research are in line with data found by Cardoso (2005), who identified that the group of countries comprised of China, India and Russia, along with Indonesia and Thailand, has large geographic and cultural distance from Brazil, internal markets and cultural and administrative distance. These countries do not share cultural and administrative features with Brazil and this has a great impact on products costs because of high transportation and insurance costs. The way for firms to supply these markets is through local production - as Embraco already does through a factory in Beijing.

Another issue raised by executives concerns the strong local competition in these markets, which has presented challenges to Brazilian and other international firms. According to Khanna and Palepu (2006), foreign firms often hesitate to adapt their products, services and communications to meet local preferences, mainly because opportunities in these countries tend to be both modest and risky. On the other hand, local firms do not face the same 
limitations, particularly because they operate in few markets and, when they improve the quality of their products or services, they manage to supply domestic consumers as well as, or better than, foreign firms.

The results show that firms sustain profitable growth in Latin American markets. $O$ Boticário and Perdigão also successfully supply African and Middle Eastern countries, which offer excellent market potential for Brazilian firms.

As noted by Cardoso (2005), the Latin American group of low-income markets for popular goods comprised of Argentina, Colombia, Mexico, Chile, Peru, Paraguay, Venezuela, Uruguay and Bolivia has a great cultural and geographic proximity with Brazil. MERCOSUL countries also have administrative proximity. This cultural and geographic proximity makes these markets receptive to Brazilian products, which in addition, are often considered to be of better quality than those produced locally. As is also noted by Cardoso (2005), there is a greater cultural and geographical distance between Brazil and Turkey, Algeria, Saudi Arabia and Iran. However, although this group of countries has internal similarities, it requires modifications in business models, products, commercialization and other variables. It is a large group, which may enable Brazilian firms to build economies of scale large enough to make any necessary alterations to products, so that they can be sold in low-income markets. This is how Perdigão and $O$ Boticário have operated in these markets.

Thus it is concluded that large popular markets like Russia, India and China present enormous challenges to Brazilian firms, as well as firms from developed countries, as detailed in the literature. Because of the difficulties Brazilian firms face to enter these markets, ideally, the best way would be to supply them through local operations or partnerships. It is harder to meet the needs of end consumers in these markets, whereas Latin American, African and Middle Eastern markets represent interesting potential for investments of Brazilian firms, and mainly those that do not have global production operations.

These results were based on the performance of six large Brazilian firms, with a history of successful international performance through commercial or production operations. But these results become even more significant if small and middle-sized Brazilian firms that manufacture and commercialize popular products for low-income markets are taken into consideration. Such challenges would make profitable performance of these small or middle firms unfeasible at the international level, in markets like China, India and Russia, due to the lack of adequate scale, relatively high costs and local competition. But Brazilian companies of this size should consider operating in Latin America, Africa and the Middle East. 
All of the firms analyzed take traditional factors into consideration when choosing their markets: market potential, GDP, income and population size. Competition and cultural factors are also relevant, as are political and economic stability, institutional environments and local government transparency.

These results mean that, when considering their performance in popular markets, Brazilian firms have to carefully analyze each of these variables, as well as consumption habits and cultural factors. The latter two variables are particularly relevant because, although a market may present similar income conditions, cultural and consumption habits may be so different as to inhibit the performance of Brazilian firms. An example in point is the case of Embraco in India, where refrigerators are used by a small portion of the populations for ice production, not for preserving food.

All of the firms analyzed in this study to some degree operate in the low-income segment both in Brazil and globally, although none of them operate exclusively in this segment, either in Brazil or overseas. All of the firms operate with a product mix that allows supplying the middle and the poor classes in the global low-income marketplace with the simpler and cheaper products from their lines. O Boticário, Natura, Perdigão, Havaianas and AmBev also supply high-income classes in the traditional markets, where they position their brands and offer premium products, with a more sophisticated and expensive line. Table 1 below shows the markets served by the different companies in the study (including populargoods markets and traditional markets).

Table 1 - Comparison Chart of Companies in the Study: Markets Served and Method of Operation

\begin{tabular}{|c|c|c|c|}
\hline $\begin{array}{c}\text { Companies in the } \\
\text { Study }\end{array}$ & $\begin{array}{c}\text { Operation in the } \\
\text { Popular-Goods Market } \\
\text { with Great Potential for } \\
\text { Brazilian Companies }\end{array}$ & $\begin{array}{c}\text { Operation in Traditional } \\
\text { Markets }\end{array}$ & $\begin{array}{c}\text { Operation in Other } \\
\text { Markets }\end{array}$ \\
\hline $\begin{array}{l}\text { Natura } \\
\text { Cosmetics and } \\
\text { perfumes }\end{array}$ & $\begin{array}{l}\text { Operations with direct } \\
\text { sales in Chile, Argentina, } \\
\text { Peru, Bolivia and Mexico } \\
\text { City }\end{array}$ & Stores in France & - \\
\hline $\begin{array}{l}\text { O Boticário } \\
\text { Cosmetics and } \\
\text { perfumes }\end{array}$ & $\begin{array}{l}\text { Franchised stores in Saudi } \\
\text { Arabia, Paraguay, Peru, } \\
\text { Uruguay, Colombia, } \\
\text { Venezuela, South Africa }\end{array}$ & $\begin{array}{l}\text { Franchised stores in the } \\
\text { U.S., Japan, Australia and } \\
\text { Portugal }\end{array}$ & $\begin{array}{l}\text { Egypt, Cape Verde, } \\
\text { Suriname, Nicaragua, El } \\
\text { Salvador, Mozambique, } \\
\text { Angola and the United }\end{array}$ \\
\hline
\end{tabular}




\begin{tabular}{|c|c|c|c|}
\hline & & & Arab Emirates \\
\hline $\begin{array}{l}\text { AmBev } \\
\text { Beverages }\end{array}$ & $\begin{array}{l}\text { Breweries (production and } \\
\text { distribution) in Argentina, } \\
\text { Uruguay, Paraguay, } \\
\text { Bolivia, Venezuela, Peru }\end{array}$ & $\begin{array}{l}\text { Breweries (production and } \\
\text { distribution) in Canada }\end{array}$ & $\begin{array}{l}\text { Breweries (production and } \\
\text { distribution) in Ecuador, } \\
\text { Dominican Republic, } \\
\text { Guatemala, Nicaragua and } \\
\text { El Salvador }\end{array}$ \\
\hline $\begin{array}{l}\text { Embraco } \\
\text { Machinery and } \\
\text { refrigerator } \\
\text { compressors }\end{array}$ & Plant in China & $\begin{array}{l}\text { Plant in Italy } \\
\text { Office in the U.S. }\end{array}$ & Plant in Slovakia \\
\hline $\begin{array}{l}\text { Perdigão } \\
\text { Foods }\end{array}$ & $\begin{array}{l}\text { Offices in the Middle East } \\
\text { (UAE) and Russia }\end{array}$ & $\begin{array}{l}\text { Offices in Japan, France, } \\
\text { Netherlands and United } \\
\text { Kingdom. } \\
\text { Distribution center in the } \\
\text { Netherlands. }\end{array}$ & \\
\hline $\begin{array}{l}\text { Alpargatas-Havaianas } \\
\text { rubber sandals }\end{array}$ & $\begin{array}{l}\text { Offices in Colombia, } \\
\text { Venezuela, Argentina, } \\
\text { Bolivia, Paraguay }\end{array}$ & $\begin{array}{l}\text { Offices in the United } \\
\text { States, Australia, France, } \\
\text { Italy and Spain }\end{array}$ & Exports to 70 countries \\
\hline
\end{tabular}

Source: Prepared by the authors through the collection of primary and secondary data

Performance in high-income markets is important for managing product brands and has a positive impact on sales in Brazil and in low-income global markets. Because low-income consumers value brand, as we have already seen, the performance in high-ncome markets reinforces the aspirational component of a product and creates a virtuous cycle, strengthening the brand so that it can compete with local products. But local products are often cheaper, which makes it hard for Brazilian firms to compete on price alone in some low-income markets.

\subsection{Critical strategic dimensions}

Based on the analysis of the cases, it is possible to present the critical strategic dimensions for Brazilian firms in popular markets.

Firms should practice a price policy aligned with the company strategy, but adapted to local markets. By and large, prices set by firms are lower in global low-income markets than in traditional markets and are defined with the support of a local partner, or of local 
executives working in subsidiaries. In the Chinese, Indian and Russian markets, prices set by local competitors are so low as to hinder the performance of Brazilian firms, particularly when there is no local production.

Strengthening the brand is very important for Brazilian producers, considering the international market. This enables them to compete in the global products category, and not only with local producers, which compete exclusively on price. Additionally, firms avoid the competition in the informal market, which, according to De Soto (2000), is very strong in these territories. The brand is also important in enhancing the aspirational character of products, reinforcing sales not only in international markets, but also in popular markets, which are highly influenced by high-income markets.

Local communication is important, and firms need to adapt their communications to local markets, to a degree that depends on the firm and performance sector. In international low-income markets, educating clients may also be necessary to help disseminate products through encouraging experimentation and changes of habit in consumers. Communication with the distribution channel, which can bring products and clients closer, is also important in low-income markets. Poor and even middle-class consumers in the global markets often have no access to the large buying centers of large cities, hence the need for communications close to consumers such as retail sales points or direct sales. Communication with local partners or executives also plays a fundamental role in educating the firm in local consumption habits and supplying the information necessary for it to adapt.

In low-income markets firms need to be able to distribute their products in a capillary manner, because in these markets they often have to deliver products to end consumers in distant places, perhaps with difficult access, unlike in traditional markets where distribution is more concentrated. Firms that sell directly to end consumers can use international partners to place their products in the market, use a direct sales system, or their own distribution system. This latter case is appropriate when a firm already has a production operation in the country. Brazilian companies have a good understanding of this, because they already supply to lowincome markets in Brazil and have developed efficient strategies to distribute their products in more difficult and poorer regions of the country, where access is very limited.

With relation to products, firms operating in low-income markets must offer more basic, simpler products than those offered in developed markets, which are more sophisticated and differentiated, with premium products more appropriate to their consumer profiles. Sophisticated markets need a more sophisticated and differentiated product mix, whereas low- 
income markets require a cheaper product line to access a low-income population. This model is in line with the product pyramid business design proposed by Slywotzky and Morrison (1998), at the international level, and also with the conclusion by Wright and Cardoso (2000), that this product pyramid model plays a strategic role in helping the firm meet the needs of different consumers with different income levels.

It is worth emphasizing that it is hard for Brazilian firms working in consumption goods to develop specific products for popular markets - this is partly due to the cultural component of each market, and partly because the international performance of Brazilian firms does not reach a scale that would justify the investment. However, Brazilian firms do manage to adapt in ways that enable them to meet the needs of international markets. The largest modifications are made to satisfy consumers in high-income markets, which have very different characteristics. Because firms already supply low-income markets in Brazil, they have an adequate product mix to also supply international low-income markets, without the need for large adaptations.

Product innovation is important for the firms studied, which seek to incorporate innovations that can be offered both in Brazil and abroad. Specific adaptations are not possible because the scale is insufficient. It is interesting to note that the theory proposed by London \& Hart (2004), which argues that the participation of local partners is necessary when innovating the content or design of new products for low-income markets, does not fully apply to Brazilian firms. On the contrary, many of the adaptations and innovations made to Brazilian products were aimed at supplying traditional markets, and demonstrated that Brazilian products are adequate to serve low-income markets as long as an adequate product mix is offered, even if this product mix included virtually the same type of products sold in Brazil. In the case of products with more technological content, the consideration argued by Prahalad (2005), that hybrid solutions have to be developed using advanced technology in a limited infrastructure, has proven to be true.

Process innovations are important to firms operating in low-income markets because they enable firms to gradually reduce their costs to compete in markets where prices are lower. Evidently, a reduction in costs that includes production costs is important for the competiveness of firms operating in low-income markets. The prices in these markets are lower - and consequently the firm needs to reduce costs to achieve sustainable results. On the other hand, these costs are also very important for the firm to compete in traditional markets, which are extremely competitive. All the firms analyzed made innovations in their processes 
to reduce costs in their Brazilian headquarters and transferred the knowledge to other production units, not only to conquer popular markets, but also to maintain competitiveness in traditional markets.

There is no one means of entrance best suited to international low-income markets, because so much depends on the type of product, opportunities, local market conditions and the firm's degree of internationalization. It is more important that the firm have a deep knowledge of the local market, through an investment partner or local executives working in commercial subsidiaries, or through acquisitions or joint ventures. Moreover, because in lowincome markets data are incomplete and information is not easily available, partnerships that enable access to market information are important for the success of firms. It is worth emphasizing that in the case of Brazilian firms, this trend is also relevant to their performance in traditional markets. In the case of the Chinese, Russian and Indian markets, where there is a large cultural and geographical distance from Brazil and local competition is very strong, the best means of entrance is through a local production operation, which must be carefully assessed by the firms, because these markets represent large risks.

Based on the set of analyses conducted, it is possible to organize the critical variables in Figure 1 below: 




Figure 1 -Internationalization variables to enter low-income markets Source: Created by the authors

\subsection{Conclusions and future studies}

The dimensions analyzed in the cases are important to the way the performance model for Brazilian firms in popular international markets is composed, as presented in the previous item. It is, however, important to highlight some strategic dimensions that are critical for success:

a. The importance of knowledge of and access to local markets (through partnerships, local leaders, company structures or acquisition of local firms);

b. The importance of brand management in international markets, including potential impact on the Brazilian market, means it is essential to position the brand in a positive manner not just in traditional but also in international low-income markets. Aspirational brand values can help this; 
c. The importance of a quality product mix, capable of supplying low-income and traditional markets according to consumer needs and available resources, and offering simpler and cheaper products to low-income markets. In contrast to multinational companies, which according to Prahalad (2005) need to innovate products to supply popular markets, Brazilian firms already have a suitable mix. Quality is valued by lowincome consumers, as detailed by Giovinazzo (2003) and Prahalad (2005), and therefore it should be a constant concern for firms;

d. Innovations in products and processes, aimed at maintaining the firm's competitiveness, reducing production costs (relevant to performance in low-income markets and competitiveness in traditional markets, where competition is very strong);

e. Existence of a well-defined business model that is sustainable over time, with long-term planning and clear internationalization strategies aligned with the firm's strategy;

f. Enhancement of long-term relationships with stakeholders, from customers to partners and investors, at the international level, because much of the international success, especially in low-income markets, depends on relationships that provide information about and access to consumers;

g. Strengthening of company culture and values for a successful internationalization, mainly when the firm is moving toward more advanced stages of internationalization, without losing sight of its strategic objectives.

The critical strategic dimensions presented in this work were identified by integrating the theory on the topic and the structured analysis of variables selected from interviews with large Brazilian firms who successfully operate in low-income markets in Brazil and abroad. The main strategic elements for a firm to successfully operate in international low-income markets were highlighted. Obviously, the application of these dimensions will vary depending on company size, investment resources available, type or product or service commercialized and also level of internationalization within the firm. However, we believe it is suitable for a first analysis by firms, as long as exceptions are made with regard to some variables, on a case-by-case basis.

Despite theoretical and methodological limitations, this study can also prove useful as a first step for scholars seeking a better understanding of the internationalization of Brazilian firms in low-income markets. It also helps firms to think about this issue in a more structured 
manner, with organized elements, which while not complete, provide an initial analysis of the options for successfully internationalizing in these markets in a profitable manner and with long-term sustainability.

Though this study considered a vast amount of literature that exists on the subject of company internationalization, the theme of internationalization in low-income markets is still recent. Therefore, the literature available was used in the absence of a more precise alternative. The very definition of international low-income markets has not yet been consolidated, so a deeper analysis of concepts was required.

Despite the fact that the multiple case methodologies used in this work do not allow for generalizing results, they have proved efficient for the purpose of this research and in proposing a theoretical model. It is worth noting that all of the steps of the research protocol were followed in a structured manner, by using primary and secondary data collection, longitudinal analysis of cases, crossover analyses, principles of the grounded theory, identification of the subtleties of the case (which at first glance do not seem to offer differentiated information on the topic) and comparison with the theoretical framework, so as to identify the strategic dimensions presented.

An interesting future analysis would be a comparison among Brazilian firms and firms from other countries operating in global low-income markets, and a comparative study, so as to verify whether these dimensions are valid only for Brazilian firms or are also valid for firms supplying low-income markets in their respective countries, because current theory often focuses on cases of multinational firms in developed markets. Another suggestion would be to apply the critical dimensions to all firms supplying the low-income market in Brazil, regardless of size and sector, thereby configuring a study of a quantitative nature, aimed at testing the hypotheses this work proposes.

\section{REFERENCES}

AAKER, D. A.; KUMAR, V.; DAY, G. S. Pesquisa de Marketing. São Paulo: Atlas, 2001.

ANSOFF, H. I. Business strategy. Penguin Books: Boston, 1984.

CALORI, R.; ATAMER, T.; NUNES, P. The dynamics of international competition. Londres: Sage Publications, 2000.

CARDOSO, M. V. O mercado internacional de bens populares: um mapeamento dos mercados potenciais para empresas brasileiras. 2005. Dissertação (Mestrado em Administração de Empresas) - Faculdade de Economia, Administração e Contabilidade da Universidade de São Paulo, 2005. 
CASTELLS, M. A sociedade em rede. São Paulo: Paz e Terra, 1999.

CAVUSGIL, S. T.; GHAURI, P. N. Doing business in developing countries: negotiations and entry strategies. Londres: Routledge, 1990.

CUI, G.; LUI, H. K. Order of entry and performance of multinational corporations in an emerging market: a contingent resource perspective. Journal of International Marketing, v. 13, n. 4, p.28-56, 2005.

CYRINO, A. B.; BARCELLOS, E. P. Estratégias de internacionalização: evidências e reflexões sobre as empresas brasileiras. In: TANURE, B.; DUARTE, R. G. (Org.). Gestão Internacional. São Paulo: Saraiva, 2006.

DANIELS. J.; DANIELS, C. Visão global. São Paulo: Makron Books, 1996.

DE SOTO, H. The mystery of capital: why capitalism triumphs in the West and fails everywhere else. Basic Books: Nova York, 2000.

DERESKY, H. Administração global: estratégica e interpessoal. Porto Alegre: Bookman, 2004.

EISENHARDT, K. Building theories form case study research. Academy of Management Review, v. 14, n. 4, p. 532-550, out. 1989.

ENGEL, J. F.; BLACKWELL, R. D.; MINIARD, P. W. Comportamento do consumidor. 8. Ed. Rio de Janeiro: LTC, 2000.

GIL, A. C. Como elaborar projetos de pesquisa. São Paulo: Atlas, 1987.

GIOVINAZZO, RENATA A. Um estudo sobre o desempenho e a estratégia das empresas que atuam no mercado de bens populares no Brasil. 2003. Dissertação (Mestrado em Administração de Empresas) - Faculdade de Economia, Administração e Contabilidade da Universidade de São Paulo, 2003.

GONÇALVES, C. A. Falando de métodos de pesquisa. Belo Horizonte, 01 de outubro, 2004.

GREEN, P. E.; CARMONE, F. J. Multidimensional scaling and related techniques in marketing analysis. Boston: Mass. Allyn and Bacon, 1988.

HAMEL, G.; PRAHALAD, C. K. Do you really have a global strategy? Harvard Business Review, p. 139-148, jul./ago. 1985.

HART, S. L.; MILSTEIN, M. B. Global sustainability and the creative destruction of industries. Sloan Management Review, v. 41, n. 1, p. 23-33, 1999.

HILL, C. W. L. International business: competing in the global marketplace. EUA: McGraw-Hill, 2005.

HITT, M. A.; IRELAND, R. D.; HOSKINSSON, R. E. Strategic management: competitiveness and globalization. Ohio: ITO, 2001. 
JOHANSON, J.; VAHLNE, J. E. The internationalization process of the firm: a model of knowledge development and increasing foreign market commitments. Journal of International Business Studies, v. 8, n. 1, p. 23-32, Spring-Summer 1977.

KHANNA, T.; PALEPU, K. G.; SINHA, J. Strategies that fit emerging markets. Harvard Business Review, p. 63-76, jun. 2005.

KHANNA, T.; PALEPU, K. G. Emerging giants: building world-class companies in developing countries. Harvard Business Review, p. 60-69, out. 2006.

KEEGAN, W. Global marketing management. Londres: Prentice-Hall, 1989.

KEEGAN, W. J.; GREEN, M. C. Princípios de marketing global. São Paulo: Saraiva, 1999.

KIRKBRIDE, P.; WARD, K. Globalization: the internal dynamic. Chichester: John Wiley e Sons, 2001.

KIRSCH, R. J.; LAIRD, K. R.; EVANS, T. G. The entry of international CPA firms into emerging markets: motivational factors and growth strategies. The International Journal of Accounting, v. 35, n. 1, p. 99-119, 2000.

KOTABE, M.; HELSEN, K. Administração de marketing global. São Paulo: Atlas, 1999.

KUADA, J.; SORENSEN, O. J. Internationalization of companies from developing countries. Nova York: Haworth Press, 2000.

LONDON, T.; HART, S. L. Reinventing strategies for emerging markets: beyond the transnational model. Journal of International Business Studies, v. 35, p. 350-370, 2004.

MAHAJAN, V.; BANGA, K. A solução dos 86\%: como ter sucesso na maior oportunidade de mercado dos próximos 50 anos. Porto Alegre: Bookman, 2006.

MALHORTA, N. Marketing research: an applied orientation. 2. ed. Upper Sadlle River: Prentice Hal, 1996.

MARINOV, M. A.; MARINOVA, S. T. Foreign direct investment in the emerging markets of Central and Eastern Europe: motives and marketing strategy. In: Yaprak, A.; Tütek, H. (Ed.). Advances in international marketing: globalization, the multinationals firms and emerging economies. Nova York: Elsevier Science, 2000. v. 10.

MEYER, K. E. Perspectives on multinationals enterprises in emerging economies. Journal of International Business Studies, v. 35, n. 4, p. 259-277, 2004.

MILES, B. M.; HUBERMAN, A. M. Qualitative data analysis: an expanded sourcebook. 2. ed. Thousand Oaks: Sage, 1994.

MINTZBERG, H.; QUINN, J. B. O processo da estratégia. Porto Alegre: Bookman, 2001.

PRAHALAD, C. K. The fortune at the bottom of the pyramid: eradicating poverty through profits. EUA: Warthon School Publishing, 2005. 
RICART, J. E. et al. New frontiers in international strategy. Journal of International Business Studies, v. 35, n. 3, p. 175-200, maio 2004.

SELLTIZ, C.; WRIGHTSMAN, L.; COOK, S. H. Métodos de pesquisa nas relações sociais. 2. Ed. São Paulo: EPU, 1987.

SLYWOTZKY, A. J.; MORRISON, D. J. A Estratégia focada no lucro. Profit zone: desvendando os segredos da lucratividade. Rio de Janeiro: Campus, 1998.

VALDÉS, J. A. Marketing estratégico e estratégia competitiva de empresas turísticas: um estudo de caso da cadeia hoteleira Sol Meliá. 2003. Tese (Doutorado em Administração de Empresas) - Faculdade de Economia, Administração e Contabilidade da Universidade de São Paulo, 2003.

WHITLEY, R. How and why are international firms different? The consequences of crossborder managerial coordination for firm characteristics and behavior. In: MORGAN, G., KRISTENSEN, P. H.; WHITLEY, R. (Ed.) The multinational firm: organizing across institutional and national divides. Nova York: Oxford University Press, 2001.

WRIGHT, J. T. C.; CARDOSO, M. V. Oportunidades estratégicas en el segmento de baja renta em América del Sur. In: CONGRESSO LATINO-AMERICANO DE ESTRATÉGIA, 12., 2000, Puebla - México. Anais... Puebla: Sociedade Latino-americana de Estratégia, 2000.

YIN, R. K. Case study research: design and methods. Califórnia: Sage, 1994.

YIP. G. Globalização: como enfrentar os desafios da competitividade mundial. São Paulo: Senac, 1996. 